\title{
BENTHAM AND MILL ON THE “QUALITY” OF PLEASURES
}

\author{
By : Francisco Vergara
}

The distinction between quantity and quality of pleasures is absent from the utilitarianism of the older generation (...) one looks in vain for it in Bentham's Principles of Morals and Legislation.

\section{Fred WILSON ${ }^{1}$}

Bentham was as concerned with quality as with quantity ... [he has been] typecast as a villain in a story in which he was presenting a shallow quantitative approach.

Frederick Rosen ${ }^{2}$

\begin{abstract}
John Stuart Mill and Jeremy Bentham are often said to have held opposed views concerning the way "the value" of different pleasures should be estimated. Mill is accused of being an inconsistent utilitarian because he thought that, when comparing the value of two pleasures, we should not forget to take their "quality" into account. Bentham, on the other hand, is said to have believed that we should take "only quantity" into consideration.

By verifying what they actually wrote, and reflecting on what they meant by words like "value", "quantity", and "quality", we find that these allegations are largely imaginary and that the difference between Mill and Bentham has (at least) been exaggerated.

Bentham, for example, did not write that "quantity of pleasure being equal, pushpin is as good as poetry", as is so often reported. In his Principles of Morals and Legislation he clearly tells us why he rejects the inaccurate word "quantity", when speaking of "the value of (a lot of) pain or pleasure", and he explicitly introduces "quality" - both the word and the concept - in his analysis of rewards and punishments.
\end{abstract}

These clarifications allow us to sort-out a few other confusions concerning utilitarianism. We explain, for example, why authors like Amartya Sen and Michael Sandel are mistaken in believing that rights and freedoms have "no intrinsic value" (only instrumental value) in utilitarian ethics.

* This is a slightly earlier version of an article that appeared in Revue d'études benthamiennes, $\mathrm{n}^{\circ} 9$, 2011. Contact address for the author http://fvergara.com

${ }^{1}$ WiLson, Fred, Psychological Analysis and the Philosophy of John Stuart Mill, University of Toronto Press, Toronto, Buffalo, London, 1990, p.191.

${ }^{2}$ RoSEN, Frederick, Classical Utilitarianism from Hume to Mill, Routledge, London and New York, 2003, p.178-179. 


\section{Introduction}

It is often claimed that John Stuart Mill and Jeremy Bentham - probably the two most famous utilitarians in history - held fundamentally opposed views concerning the way "the value" of different pleasures should be estimated. Mill, for example, has been accused, again and again, of being an inconsistent utilitarian because he held that, when comparing the value of two pleasures, we should not forget to take their quality into account. Bentham, on the other hand, is said to have been more consistent, but less subtle, because he thought that we should take only quantity into consideration.

Allegations like these appeared almost immediately after Mill's Utilitarianism was published in 1861. In his 1882 book of Recollections on John Stuart Mill, for example, Alexander Bain already tells us that:

[Mill's] two or three eloquent pages (...) in favor of a difference in kind or quality among pleasures (...) have received more attention from critics than all the rest of the book put together. ${ }^{3}$

And, like many others, Bain disagrees with Mill on this point:

I do not see a difference of quality at all (...) I consider Mill's Hedonism weak. $^{4}$

Some twenty years later, in his famous Principia, G. E. Moore writes something in the same vein:

if you say, as Mill does, that "quality" of pleasure should be taken into account, then you are no longer holding that pleasure alone is good as an end, since you imply that something else is also good as an end.

far from establishing the principle that pleasure alone is good [Mill's introduction of "quality" into the evaluation] is obviously inconsistent with it. ${ }^{6}$

And of Bentham he writes:

it is well known that Bentham rested his case for Hedonism on "quantity of pleasure" alone. ${ }^{7}$

Opinions like these (especially about Bentham) are repeated over and over nowadays. The Encyclopaedia Britannica, for example, writes that "Mill, in

\footnotetext{
${ }^{3}$ BAIN, Alexander, John Stuart Mill; A Criticism: With Personal Recollections, p.113. Emphasis added.

${ }^{4}$ BAIN, Alexander, John Stuart Mill, pp.112 and 114

${ }^{5}$ MoORe, George Edward, Principia Ethica (1903), Cambridge University Press, New York, 1992, p.80. Quotation marks and emphasis are Moore's.

${ }^{6}$ MoOre, George Edward, Principia, p.79. Emphasis added.

${ }^{7}$ Moore, George Edward, Principia, pp.77-78. Quotation marks are Moore's.
} 
contrast to Bentham, discerned differences in the quality of pleasures". And the Stanford Encyclopedia of Philosophy says something similar: "[Mill] argues, in contrast to what Bentham implied, that quality, not simply the amount of pleasure, is to be taken into account".

Several scholars have protested against the somewhat cavalier practice of accusing Mill, so lightly, of "fallacies which an elementary student can detect" (as Professor D. D. Raphael puts it). ${ }^{10}$ But very few have objected against the serious charges leveled at Bentham. Professor Frederick Rosen - see our epigraph - is one of the rare exceptions. Professor Ross Harrison also gives us a different picture of Bentham's thought on this subject:

Bentham himself was always more interested in quality than quantity ... [his] analysis is qualitative rather than quantitative. ${ }^{11}$

To shed some light on this enduring debate, we first try to clarify what the discussion is about, and a good place to start is to identify the different senses (the different acceptations) in which the key words (value, quantity, quality, etc.) are used by the protagonists. That way we can, at least, determine which part of the disagreement is simply due to a different use of words.

The principle involved here is quite simple. If we are aware of the different acceptations that a word like "quality" possesses, the exact sense in which it is used in any given sentence becomes clear from the context. But, if the different acceptations have not previously been distinguished and demarcated in our mind, and if the phrase or sentence in which the word appears is quoted by itself (out of its context), a misunderstanding can creep in and take on a life of its own, as seems to have happened with Mill's famous paragraphs on "quality", in his book Utilitarianism.

\section{The difference between "value" and "pleasantness"}

Since the discussion concerns the way that "the value" of different pleasures should be estimated, according to Bentham and Mill, the first thing to clear up is what these authors meant by the word "value".

If the supreme good is - according to utilitarians - a life as happy as possible, the value of a certain type of pleasure (or the value of anything else) is simply its contribution to this end. If a given type of pleasure - massages, football, poetry or music - tends to contribute much to the happiness of life, it has much value; if its contribution is very small, it has little value.

\footnotetext{
8 "Utilitarianism", Encyclopaedia Britannica. On the Web: http://www.utilitarianism.com. Emphasis added.

9 "John Stuart Mill", Stanford Encyclopedia of Philosophy. On the Web: http://plato.stanford.edu/entries/mill. Emphasis added.

${ }^{10}$ RAPHAEL, D. Daiches, "Fallacies in and About Mill's Utilitarianism”, Philosophy, vol. 30, 1955, p.344.

${ }^{11}$ Harrison, Ross, Bentham, Routledge \& Kegan Paul, London, Boston, Melbourne and Henley, 1983, pp.149 and 162 .
} 
If we accept this use of the word, it becomes clear that "the value" of something should not be confused with its "pleasantness" (how "pleasurable" or "grateful to the feelings" it is). ${ }^{12}$ Many things have great value (contribute greatly to a happy life) but can be very unpleasant, like chemotherapy, penicillin shots, punishment and tooth drilling, just to mention a few. And many things can be very pleasant, like candy, ice-cream, tobacco, and hard drugs, but not have great value (not contribute much to a happy life).

The difference between pleasantness and value is not very difficult to grasp. When comparing the pleasantness of two things, we take into account only the pleasant sensations and feelings they produce directly in our minds (the first order effects, one might say), whereas when we compare their value, we also take into account their indirect (or second order) effects, like the enjoyments they open doors to in the future, as well as the unpleasant things they will allow us to avoid (like obesity, lung cancer, ill health, etc.). The value of something includes all of these elements, not just its immediate pleasantness.

So, when someone asks if pushpin or football are "as good as" poetry and music (or "better than" poetry and music), the first thing to do is to ask if he is talking about their pleasantness or about their value. And if it is about their value we are speaking, we should ask him if he is referring to their value for the person concerned or for humanity. All of these questions are perfectly legitimate, but they should not be confused.

\section{Different senses of the word "pleasure"}

The next thing to clear up is the different senses in which the word "pleasures" is used in these discussions. The word seems to have (at least) three different acceptations.

In a first sense, it serves as a generic name denoting pleasant activities, pleasant ways of spending time (like arts, sciences, sports, hobbies, pastimes, etc.). This is very clear when we speak of pleasures like music, poetry, football or pushpin.

But the word also has a second and very different acceptation. It is also used as a generic name for denoting pleasant mental states or pleasant sensations and feelings (not the activities which produce such feelings, but the feelings themselves). In contrast with pleasant activities (like football, music and pushpin), pleasant sensations and feelings rarely have individual names reserved exclusively for them, but they can be told apart and distinguished by describing the circumstances in which they commonly arise. Thus the enjoyment received from listening to classical music is clearly different from the merriment we feel after listening to a good joke, or the satisfaction obtained by scratching one's back (when it itches).

The word pleasure is also sometimes used in a third way, not as a "generic name" for pleasant mental states, but as the name of a more or less homogenous "ingredient" that these states are supposed to contain. So we sometimes find sentences like "which of two mental states contains more pleasure?" or "more units

\footnotetext{
${ }^{12}$ In A System of Logic (1843) Mill uses the word "pleasantness" the way we use it here, but in Utilitarianism (1863) he conveys this meaning with expressions like "pleasurable" and "grateful to the feelings".
} 
of pleasure?" As if we said that all beautiful things (like paintings, sculptures and scenery), contain a certain amount of an ingredient called "beauty", and we said of this or that painting that it contains more units of "beauty". This third way of using the word does not seem helpful for making the points we wish to make in this paper, so we do not use it here.

\section{Three acceptations of the word "quality"}

We come now to the crucial word in this debate: "quality". Let's just take three meanings that will help us understand the way Mill uses the expression in Utilitarianism and allow us to distinguish it from the misunderstanding of the word by authors like Moore.

In a first sense, the word "quality" means the qualities, properties or powers that something has. We say of snow, for example, that it has the quality of being white and cold, by which is meant that it has the power of producing, in our minds, the ideas or feelings that we call "white" and "cold". This is the acceptation in which John Locke uses the word:

the Power to produce any Idea in our mind, I call Quality of the Subject wherein that power is. Thus a Snowball having the power to produce in us the Ideas of White, Cold, and Round, the Powers to produce those Ideas in us, as they are in the Snowball, I call Qualities. ${ }^{13}$

When used in this sense, the word is often written in the singular (Quality) but is really plural (Qualities), like the expression "the Law of the land" which actually means "the laws" of a country.

In a second sense, when the word "quality" is opposed to "quantity", it is $a$ name or label under which we class the properties or qualities that something possesses other than quantity. This is the acceptation that Mill gives in sections "Quantity" and "Quality" of his System of Logic:

Let us imagine two things, between which there is no difference (that is, no dissimilarity) except in quantity alone: for instance, a gallon of water, and more than a gallon of water. A gallon of water, like any other external object, makes its presence known to us by a set of sensations which it excites. Ten gallons of water are also an external object, making its presence known to us in a similar manner; and as we do not mistake ten gallons of water for a gallon of water, it is plain that the set of sensations is more or less different in the two cases. In like manner, a gallon of water, and a gallon of wine are two external objects, making their presence known by two sets of sensations, which sensations are different from each other. In the first case, however, we say that the difference is in quantity; in the last there is a difference in quality. ${ }^{14}$

\footnotetext{
${ }^{13}$ LOCKE, John, An Essay concerning Human Understanding, Clarendon Press-Oxford, New York, 1975., p.134. Emphasis and capital letters are Locke's.

${ }^{14}$ MILL, John Stuart, A System of Logic, The Collected Works of John Stuart Mill, University of Toronto Press, Routledge \& Kegan Paul, Vol. VII, 1974, p.73. Emphasis added.
} 
The important thing to grasp here is that, when Mill writes that "there is a difference in quality", he is not making a value judgement. He is not asserting that wine is better than water or that water is better than wine. He is only saying that they are dissimilar and that the difference lies not in their quantity but in their quality (qualities). He could have said the same thing about any other two substances or materials, whether a pound of rice compared with a pound of wheat, or a bucket of white sand compared with one of beige sand. Since he is not making a value judgement, he is - a fortiori - not making one that is inconsistent with utilitarianism.

When the word "quality" is opposed to "vulgarity" or "commonness", it takes on a third meaning indicating "nobleness" or "superiority" (as when one speaks of "people of quality" or "quality time"). When it is used this way, there is generally an implicit (unmentioned) standard of value being used.

It should not be too difficult to identify the sense in which an author uses the word in any given sentence; we should be able to see if he is using it in opposition to "quantity" or to "vulgarity". But the mental association of the word "quality" with the idea of "refined taste" is so strong that many readers slide inadvertently from the second sense of the word to the third, and confuse them, as some of Mill's critics seem to have done. And the common use of language helps us make this confusion.

Take a litre of wine, for example. The volume it occupies constitutes its quantity whereas its remaining properties (flavours, aromas, texture, balance, etc.) constitute its quality. If we compare an identical quantity of two different wines, they produce in our minds two sets of sensations that are different, and we can say (as Mill does about a gallon of wine and a gallon of water) that "there is a difference in quality".

Up to this point, no value judgement has been made. It is simply asserted that there is a difference, and that the difference lies in the quality (since it does not lie in the quantity).

For there to be a value judgement, we would have to (consciously or inadvertently) introduce a standard of value or of goodness (like "pleasure", for example). If the flavours, aromas, and other properties of one of the wines produce pleasant sensations, we say that it is a wine "of good quality". If they produce unpleasant sensations, we say that it is a wine "of bad quality".

But, here now is where a confusion can slip-in. Though we never omit the word "bad", when speaking of wines "of bad quality", in common language we often leave out the word "good" when talking of good ones, and simply say that it is "a wine of quality". The word "quality" seems to become a value judgement on its own. This way of speaking simply means that the pleasure this wine gives comes from those of its properties that we class under quality (flavours, aromas, etc.), and not from those classed under quantity (litres).

It is one of those many words that seem to have a normative connotation because of the implicit (unwritten) adjective with which they are often associated. As the word "morals" in the expression "a man of morals", which really means a man of "good morals". 


\section{5. "Intrinsic" and "extrinsic" value}

John Stuart Mill also writes, now and then, that some kinds of pleasures have an "intrinsic superiority" 15 over others. Like the expression "qualitative superiority", this manner of speaking has also been suspected of smuggling-in a non-utilitarian standard of value. The reason is that the word "intrinsic" (like the word "qualitative") has several different acceptations that can easily be confused if we have not previously identified and distinguished them.

In everyday language, the adjective "intrinsic" conveys the feeling that something is very important. Thus, when certain religious leaders tell us, for example, that something is "intrinsically wrong" (that it is "an intrinsic evil") it awakens very strong emotions of disapproval. On the other hand, when it is said of something that it has "no intrinsic value", it conveys the feeling that it is not as important as other things that do have such value.

In ethical discussions, the word has a very different acceptation. It does not at all mean that something is "very important" or "very valuable". It means only that its value (whether enormous or microscopic) comes from itself, and not from its consequences or circumstances. ${ }^{16}$

The meaning of this word becomes clearer if we recall that the utilitarian moralist is interested not only in the value of pleasures. He is interested in the value of everything, even pains (unpleasant things). The reason is that some painful things (like chemotherapy or punishment) can have more value (contribute more to happiness) than some very pleasant things like pastries, candy or ice cream.

The idea behind this paradox is sometimes (and very correctly) expressed by saying that the value of pastries and candy is "intrinsic", which simply means that their value lies in themselves or, more exactly, in their own pleasantness and not in the pleasantness of their consequences. On the other hand, the value of certain painful things, like chemotherapy, is entirely extrinsic or instrumental. In themselves they are unpleasant, their value coming entirely from the pleasantness of the consequences they produce or open doors to. As Mill puts it, these things are "a means to good, not intrinsically a good". ${ }^{17}$

We can easily see that the expression "intrinsic superiority" carries no mysterious or hidden value judgement when we realize that Coca-Cola, for example, has more intrinsic value than penicillin or vaccines (which probably have none). This simply means that all (or most) of Coca-Cola's value (whether enormous or negligible) lies in its own pleasantness, and not in that of its consequences. On the other hand, all of penicillin's value lies in its consequences and not in its pleasantness.

The words "intrinsic" and "extrinsic" are not the only ways of expressing this difference. Another way is to write that the value of things like candy, or ice cream, comes from the pleasure "inherent" in them, and not in their consequences. As Mill writes:

\footnotetext{
${ }^{15}$ MILL, John Stuart, Utilitarianism, The Collected Works, Vol. X, 1969, p.212.

${ }^{16}$ This is not the use of the word in utilitarian discussions only. For a clarification of what the word means in Thomist ethics, see for example, "Intrinsic Evil and Political Responsibility", by Notre Dame Professor Cathleen Kaveny, America Magazine, October 27, 2008.

${ }^{17}$ MiLL, John Stuart, Utilitarianism, p.239. Emphasis added.
} 
all desirable things (which are as numerous in the utilitarian as in any other scheme) are desirable either for the pleasure inherent in themselves, or as means to the promotion of pleasure and the prevention of pain. ${ }^{18}$

It is sometimes also said that they have value "as pleasures" whereas penicillin and chemotherapy have value "as causes" or "as means of attaining" pleasure. As Mill puts it:

nothing is a good to human beings but in so far as it is either itself pleasurable, or a means of attaining pleasure or averting pain. ${ }^{19}$

\subsection{The intrinsic value of rights and freedoms}

This clarification of what the word "intrinsic" means, allows us to comment on an enduring misunderstanding often entered into by authors like Amartya Sen, who accuse utilitarians of believing that rights and freedoms have no intrinsic value, only instrumental value. Freedom of discussion, for example, would have value only because it allows us to identify and redress false opinions; free elections have value because they allow us to remove bad leaders, etc.

The more fair-minded of these critics concede that utilitarians count, among the many good consequences of freedom of discussion and free elections, their educational effects: a sharpening of the mind, the development of an interest in public affairs, etc.. The accusation remains nevertheless that, as long as we find some other "instrument" producing the same useful consequences, nothing important is lost if these rights are restricted since they have "no intrinsic value".

These critics are wrong on two counts. First of all, as we saw above, the fact that something has "no intrinsic value" does not imply that it is less important than other things. Some of the most important institutions for a happy society (taxes and prisons, for example) are, in a greater or lesser degree, unpleasant in themselves but have, through their consequences, enormous value.

Second of all, in the utilitarian system everything that is pleasant in itself has intrinsic value. And anyone who has lived through a period of oppression knows how unpleasant it is to be deprived of freedom of expression and how pleasant it is to recover it afterwards (independently of the well-known beneficial consequences of free discussion).

Freedom of expression is so unpleasant to be deprived of (has so much intrinsic value) that people who are accustomed to it would not accept a life without it in exchange for a life containing any amount of ice-cream, tobacco, wine or whatever other pleasure of "mere sensation" they may happen to enjoy. As Mill writes (in an often misunderstood phrase), they "would not resign it for any quantity of the other pleasure which their nature is capable of". ${ }^{20}$

This is what Mill means when he writes that, for those who have become familiarized with them, the pleasures "of the intellect, of the feelings and

\footnotetext{
${ }^{18}$ Utilitarianism, p.210. Emphasis added.

${ }^{19}$ MiLL, John Stuart, Utilitarianism, p.239. Emphasis added.

${ }^{20}$ MiLL, John Stuart, Utilitarianism, p.211. Emphasis added.
} 
imagination, and of the moral sentiments" ${ }^{21}$ have an intrinsic superiority over the pleasures of "mere sensation". The word "intrinsic" simply points to the fact that the superior value of these pleasures lies not only in their excellent consequences; but also in the fact that they are better as pleasures.

What seems to trouble authors like Sen is that when utilitarians elevate a freedom (like freedom of expression) to the rank of "a right" - meaning that society has the duty to intervene if someone is deprived of it - they do not do this because of its "intrinsic value" (its pleasantness); they do it because of its "public utility" (its consequences and implications for the happiness of the community).

A similar mistake is made by Harvard Professor Michael Sandel, who writes that Utilitarians "do not assert that torturing a human being is intrinsically wrong, only that practicing torture will have bad effects". 22 The truth is almost the exact opposite. All utilitarians consider torture to be intrinsically wrong; some utilitarians think that it can occasionally have good effects (avoid a catastrophe).

The explanation, here again, is quite simple. "Pain" is the very definition of evil for utilitarians. And torture - being deliberately designed to cause physical or mental pain - is undoubtedly evil. Some Stoics may believe that "pain is no evil", utilitarians do not.

But, is torture an intrinsic or an extrinsic evil? Or both? Though many utilitarians believe that, if everything is considered, it will globally produce bad effects (which would make it an extrinsic evil), all utilitarians believe that it is very unpleasant in itself, which makes it an intrinsic evil.

There remains, of course, the practical question of what the right thing to do is in certain difficult and complex situations in which a utilitarian sincerely believes that an even greater evil might be prevented by allowing torture. First of all, as we saw above, the classification of torture in the category of "intrinsically evil" things does not help answer the question. And second of all, confronted with these problems utilitarians are no more divided than the adherents of any other doctrine of right and wrong.

\section{What exactly was Mill criticizing utilitarians for?}

What exactly was Mill accusing fellow utilitarians of, when he writes that we should not forget to take "quality" into account when estimating the value of pleasures?

Let's start by making clear that he was not accusing them of denying that some kinds of pleasures are better as pleasures than others; in particular that mental pleasures are better as pleasures than bodily sensations. He believed that no-one worthy of the name of philosopher had ever denied this:

there is no known Epicurean theory of life which does not assign to the pleasures of the intellect, of the feelings and imagination, and of the

\footnotetext{
${ }^{21}$ MILL, John Stuart, Utilitarianism, p.211.

${ }^{22}$ SANDEL, Michael, Justice, What's the Right Thing to do? Penguin Books, 2010, p.39. Emphasis added.
} 
moral sentiments, a much higher value as pleasures than to those of mere sensation. $^{23}$

Of his father, James Mill, he tells us that:

He never varied in rating intellectual enjoyments above all others, even in value as pleasures, independently of their ulterior benefits. ${ }^{24}$

Bentham himself clearly preferred music above all other pleasures:

Music was throughout life his favourite amusement (...) Much more has been said than there is any foundation for, about his contempt for the pleasures of imagination, and for the fine arts. ${ }^{25}$

So, what is the reproach?

Mill, as well as the utilitarians that he criticizes, completely agree on the fact that the pleasures of the intellect and the feelings are better than those of mere sensation. And both agreed that they are better on two counts: as pleasures and because of their consequences. What Mill regrets is that, when his fellow utilitarians advice their disciples to develop their taste for intellectual pleasures and base their life's happiness on the cultivation of these (rather than on bodily ones), they put the emphasis on their better consequences, and not on their greater pleasantness (which, as we saw above, he does not accuse them of denying). They point "chiefly" (not exclusively) to the extrinsic advantages of the first, and not to their intrinsic superiority:

It must be admitted, however, that utilitarian writers in general have placed the superiority of mental over bodily pleasures chiefly in the greater permanency, safety, uncostliness, \&c., of the former - that is, in their circumstantial advantages rather than in their intrinsic nature.

When trying to convince their readers, "utilitarian writers in general" place the superiority of these pleasures chiefly on the fact that they can be enjoyed during more time (they do not reduce life expectancy), by more people (because they are less costly), and with more certainty (they are less liable of being interrupted by poverty, ill health or old-age). These are all excellent and well argued points, and according to Mill "on all these points utilitarians have fully proved their case", 27 but they are arguments about quantity (duration, certainty, percentage of the population having access to them, etc.). Without neglecting these arguments,

\footnotetext{
${ }^{23}$ MiLL, John Stuart, Utilitarianism, p.211. Emphasis added.

${ }^{24}$ MiLl, John Stuart, Autobiography (Penguin Books, London and NewYork , 1989), p.56. Emphasis added.

${ }^{25}$ MiLl, John Stuart, Bentham, The Collected Works of John Stuart Mill, Vol. X, Essays on Ethics, Religion and Society, University of Toronto Press, Routledge \& Kegan Paul, 1969, p.113. Emphasis added.

${ }^{26}$ MiLL, John Stuart, Utilitarianism, p.211. Emphasis added.

${ }^{27}$ MiLL, John Stuart, Utilitarianism, p.211.
} 
utilitarians could - with no inconsistency - have put the emphasis on quality, on the fact that these activities are more pleasant:

they might have taken the other, and, as it may be called, higher ground, with entire consistency. ${ }^{28}$

And then comes his famous phrase:

It would be absurd that while, in estimating all other things, quality is considered as well as quantity, the estimation of pleasures should be supposed to depend on quantity alone. ${ }^{29}$

\section{The "Maxim" that Bentham didn't write}

As we saw above, Bentham is often accused of believing that, when comparing the value of two pleasures, we should take only quantity into consideration. He is even said to have had an aphorism on the subject. As G. E. Moore writes: "It was his maxim, that "quantity of pleasure being equal, push-pin is as good as poetry"', 30 More recently, Oxford Professor Alan Ryan calls this maxim "One of Bentham's most famous remarks" and he tells us that "This is, in Bentham, a necessary truth". 31

The maxim - as Moore calls it - has been quoted again and again in academic literature, and has become one of the most popular renderings of Bentham's thought concerning the value of pains and pleasures.

Now there is a serious problem with this maxim: it isn't Bentham's. In the original text in which Bentham explains how a utilitarian should proceed, when comparing the value of pleasant activities like pushpin and poetry, the word "quantity" is not used at all.

The often misquoted phrase concerning push-pin and poetry, comes from the chapter "Art and Science - Divisions" of Bentham's book The Rationale of Reward, where he discusses the contribution to human happiness of the different Arts, Sciences, Hobbies, etc. And, like Mill, he uses the word "value" to denote this contribution:

the value which they possess, is exactly in proportion to the pleasure they yield (...) Prejudice apart, the game of push-pin is of equal value with the arts and sciences of music and poetry. If the game of push-pin furnish more pleasure, it is more valuable than either. Everybody can play at push-pin: poetry and music are relished only by a few. ${ }^{32}$

\footnotetext{
${ }^{28}$ MILL, John Stuart, Utilitarianism, p.211.

${ }^{29}$ MILL, John Stuart, Utilitarianism, p.211.

${ }^{30}$ Moore, George Edward, Principia, p.77-78. Quotation marks are Moore's, emphasis added.

${ }^{31}$ RYAN, Alan, "Moving on from Bentham: Quantity and Quality", Utilitarianism, Third Lecture, http://users.ox.ac.uk/ ajryan/lectures/Utilitarianism/Mill\%20Lecture\%203.pdf. Emphasis added.

${ }^{32}$ BENTHAM, Jeremy, The Rationale of Reward, The Works of Jeremy Bentham, (Bowring edition), book III, ch. I, http://www.laits.utexas.edu/poltheory/bentham/rr/index.html. Emphasis added.
} 
As the reader will have noticed, Mill (in Utilitarianism) and Bentham (in The Rationale of Reward) are speaking of two different things. In John Stuart Mill's famous lines on "quantity" and "quality", what is being discussed is the value of different kinds of pleasures for the individual. In Bentham's paragraphs (in which the word "quantity" is never used), what is being discussed is their value for society. So, since they are not asking the same question, there would not necessarily be any contradiction if Mill believed that poetry and music are better (because they are more pleasant once we have learned to enjoy them) while Bentham considered that push-pin is better (because more people have access to it).

The fact is that, in the chapter we are quoting, Bentham did not hold that pushpin has more value (or as much value) for society as music and poetry, though his provocative way of speaking may give that impression when one or two phrases are read out of context. What he really says is that, if the fine arts (music, poetry, etc.) have greater value for society, it is probably not so much because of the pleasure they give (to the elite few who appreciate them) as because of the pain they prevent (for the many who do not). They have (historically) prevented much pain for society by turning the activity of its most powerful and energetic members away from the harmful channels that it would otherwise have gone into (mainly war). Here is his argument:

If poetry and music deserve to be preferred before a game of push-pin, it must be because they are calculated to gratify those individuals who are most difficult to be pleased (...) They compete with, and occupy the place of, those mischievous and dangerous passions and employments, to which want of occupation and ennui give birth (...) It is to the cultivation of the arts and sciences, that we must in great measure ascribe the existence of that party which is now opposed to war: it has received its birth amid the occupation and pleasures furnished by the fine arts. These arts, so to speak, have enrolled under their peaceful banners that army of idlers which would have otherwise possessed no amusement but in the hazardous and bloody game of war. ${ }^{33}$

As we see then, Mill and Bentham do not so much contradict, as they complement one another on this subject. Mill is addressing people who want to have a happy life, and he is reminding them not to forget to take quality into account when they choose their pleasures. Bentham is addressing those who want to know which arts, sciences and pastimes contribute most to the happiness of society. And he reminds them to take into consideration not only how much pleasure they add, but also how much pain they prevent.

More generally, his opinion is that, when discussing the value that these activities have for society, we should not be influenced by prejudices - about "fine arts" as opposed to "popular amusements"; about what is, and what is not, "good taste" - and study the question open-mindedly considering all sides of the question.

\footnotetext{
${ }^{33}$ BENTHAM, Jeremy, The Rationale, book III, ch. I. Emphasis added.
} 


\section{Further considerations on "quantity" and "quality"}

Coming back to Mill's argument on the quality of pleasures, it becomes clearer if we consider things step by step. Let's first take objects that we can see, touch and taste, like wines for example. Those who are familiar with them can easily distinguish several of their pleasure-producing properties (aromas, flavours, texture, robe, structure, bouquet, body, finish, balance, etc.). It doesn't seem to be an abuse of language to class some of these properties under the label "quantity", and others under "quality". That seems to be the use of these words in John Stuart Mill's Logic.

If we next consider things that we can only hear (like music) or smell (like odors and scents), identifying their pleasure-producing properties and giving them names is more difficult and requires the specialised training of a musician or a perfumist. But it does not seem very controversial to suggest that some of these properties can be classed under the label quality, rather than quantity.

When we come to things of the mind, things that we can "observe" only by introspection, like our sensations and feelings, it seems natural to ask why they should be treated differently. If "all other things" 34 have properties that can be classed under quantity and quality, why should phenomena of the mind be an exception? And, if we take quantity and quality into consideration when we estimate the value of wines, perfumes and music, why shouldn't we do the same for the pleasant sensations and feelings we cultivate?

\section{1 "Duration", "intensity” and other properties}

A first property of sensations and feelings that everyone classes under "quantity" is their duration (how long they last). Though all other properties could be classed under "quality", it has become customary to also include intensity under the label "quantity". The question under discussion is whether duration and intensity are the only properties of sensations and feelings that contribute to their pleasantness or painfulness, and if this is what Bentham taught.

What "duration" is, anyone can grasp and it can be measured in seconds, minutes and hours. As for "intensity", we seem to have here, once again, one of those words that has several meanings. If we mean by it all of the pleasure giving properties of a feeling (apart from its duration), then it would be tautological to say that, when comparing the value of two feelings we should take only duration and intensity into account. But, in its most common acceptation, the word has a more restricted sense and refers only to a part (not to all) pleasure giving properties.

A few examples can illustrate this more restricted sense of the word. Some popular amusements, like a roller-coaster ride or jumping off a bridge attached to an elastic chord, produce pleasures that are more intense than resting quietly by a softly flowing stream or enjoying a beautiful sunset. The feelings aroused by Wagner's "The Ride of the Valkyries" are more intense than those produced by the soothing movements of Handel's Water Music. When we see an act of violence

\footnotetext{
${ }^{34}$ MILL, John Stuart, Utilitarianism, p.211.
} 
being done, the unpleasant feeling we experience is more intense than when we see a simple act of impoliteness.

In this more restricted sense of the word, we can no longer say - of pleasant feelings - that "the more intense the better". A soothing and calm feeling, for example, can be more pleasant than a very intense one of equal duration. This is often the case when we are tired, when one has already had so many intense pleasures that they have become less interesting. Or if one has simply developed the capacity of distinguishing, and the habit of enjoying, properties like "nuance", "subtlety", "delicacy", "balance", "shade", "touch", "tone", or whatever names one wishes to give to pleasure-giving-properties other than duration and intensity. If we reflect on any of the sensations or feelings that we normally search for as enjoyments, it is clear that we do not always consider the most intense as the most enjoyable. Intensity seems to be, for pleasant feelings, like salt and pepper are for food: there can be too much or too little.

This seems to be the sense in which Mill uses the word in Utilitarianism. And when he speaks of the pleasures his father preferred, it is clearly in this more restricted sense that the word is used:

"The intense" [quotation marks are Mill's] was with him a bye-word of scornful disapprobation (...) For passionate emotions of all sorts, and for everything which has been said or written in exaltation of them, he professed the greatest contempt. He regarded them as a form of madness. ${ }^{35}$

Mill doesn't try to give a list of the properties that we can class under the label "quality", to prove that they exist, it is enough if we are able to feel them:

If I am asked, what I mean by difference of quality in pleasures, or what makes one pleasure more valuable than another, merely as a pleasure, except its being greater in amount, there is but one possible answer (...) If one of the two is, by those who are competently acquainted with both, placed so far above the other that they prefer it (...) and would not resign it for any quantity of the other pleasure which their nature is capable of, we are justified in ascribing to the preferred enjoyment a superiority in quality. ${ }^{36}$

To grasp his meaning, we can each compare, in our minds, two pleasures with which we are "personally" and "competently" acquainted with. Drinking "wine" (or "coffee"), compared with "reading philosophy books", for example.

The point is that many people competently acquainted with both, would not give up reading philosophy books for "any quantity" of coffee or wine that their nature is capable of enjoying. And if a majority of people acquainted with these pleasures agree, we are comforted in our inference. As Mill puts it, we are justified in ascribing to the preferred enjoyment a superiority in quality.

This is also the only way to prove superiority in quantity. How else do we know that the pleasant sensation produced by Wrigley's Chewing-Gum lasts longer than

\footnotetext{
${ }^{35}$ MiLl, John Stuart, Autobiography, p.56.

${ }^{36}$ MILL, John Stuart, Utilitarianism, 211. Emphasis added.
} 
that of other brands of gum? By the testimony of those who are acquainted with Wrigley's and non-Wrigley's gum. How else can we know that the sensation produced by Fisherman's Friend is more intense than that of its rival eucalyptus drops? By the testimony of those who are acquainted with both. There is no other tribunal.

\section{Bentham on "quantity and quality"}

The accusations against Bentham have been around for many years. Michael Sandel, for example, writes that:

The only basis for judging one experience better or worse than another is [for Bentham] the intensity and duration of the pleasure or pain it produces (...) Bentham recognizes no qualitative distinction among pleasures. $^{37}$

Alasdair MacIntyre is just as categorical:

In choosing between alternatives, quantity of pleasure is [for Bentham] the only criterion. ${ }^{38}$

These strong assertions require some comments.

First of all, let's remember that in the famous chapter "Value of a Lot of Pleasure or Pain: How to be Measured", 39 of his book An Introduction to the Principles of Morals and Legislation, Bentham never uses the word "quantity". Just as he does in The Rationale of Reward, he speaks of "value" (as the title of the chapter clearly indicates). In his usual methodical way, he explains why he rejects the word "quantity", but he only does so ten chapters later:

Let us look back a little (...) It is to be observed, then, that for the sake of accuracy, it was necessary, instead of the word quantity to make use of the less perspicuous term value. For the word quantity will not properly include the circumstances (...) which, in estimating the value of a lot of pain or pleasure, must always be taken into account. ${ }^{40}$

It is true that, in this very short little chapter (three and a half pages), he does not use the word "quality", and he does not speak of the different properties of pains and pleasures that he would class under that label. But, why should we suppose that he did not discern quality (or, that while seeing it, he refused to take it into

\footnotetext{
${ }^{37}$ SANDEL, Michael, Justice, What's the Right Thing to do?, Penguin Books, 2010, p.52. Emphasis added.

${ }^{38}$ MACINTYRE, Alasdair, A Short History of Ethics, University of Notre Dame Press, Indiana, second edition, 1998, p.234. Emphasis is MacIntyre's.

${ }^{39}$ The expression "a lot of", as used by Bentham, means a basquet, bundle or bunch of things. See "Some definitions" at the end of this paper.

${ }^{40}$ Bentham, Jeremy, An Introduction to the Principles of Morals and Legislation, Clarendon Press, New York, 1996, p.169. Emphasis is Bentham's.
} 
account)? Maybe he was just concentrating on the measurable properties of lots of pain and pleasure (as the title of the chapter suggests). Maybe - as he says at the beginning of the immediately following chapter "Pleasures and Pains, Their Kinds" - he was concentrating on "what belongs to all sorts of pleasures and pains alike", and not on what distinguishes them one from another and makes them different in quality or kind.

Whatever may be the reason, ten chapters later, when speaking of punishment, he explicitly introduces the word "quality". First he tells us that "a lot of punishment is a lot of pain" 41 and then, when enumerating the "circumstances" that one should have in mind when inflicting punishment, he explicitly adds "quality":

It may be of use, in this place, to recapitulate the several circumstances, which, in establishing the proportion betwixt punishments and offenses, are to be attended to. These seem to be as follows $(\ldots)^{42}$

II. On the part of the punishment:

5. The magnitude of the punishment: composed of its intensity and duration:

6. The deficiency of the punishment in point of certainty;

7. The deficiency of the punishment in point of proximity;

8 . The quality of the punishment ... ${ }^{43}$

By quality, he means the properties that different punishments posses, apart from their intensity, duration, certainty and proximity (which also have the power of influencing the mind). Elsewhere, using a physical analogy, he speaks of quantity as "the force (...) of the impulse that the mind receives" from a lot of pains and pleasures, and of quality as the "direction of those impulses", the direction in which they tend to move the mind. ${ }^{44}$

He mentions many of these qualitative properties in different parts of the book, in particular in chapter XV "Of the Properties to be Given to a Lot of Punishment". Let's just recall one of them, what Bentham calls its "reforming tendency":

A seventh property, therefore, to be wished for in a mode of punishment, is that of subserviency to reformation, or reforming tendency. Now any punishment is subservient to reformation in proportion to its quantity: since the greater the punishment a man has experienced, the stronger is the tendency it has to create in him an aversion towards the offense which was the cause of it: and that with respect to all offenses alike. But there are certain punishments which, with regard to certain offenses, have a particular tendency to produce that effect by reason of their quality.

\footnotetext{
${ }^{41}$ Bentham, Jeremy, An Introduction to the Principles of Morals and Legislation, Clarendon Press, New York, 1996, p.169.

${ }^{42}$ BENTHAM, Jeremy, An Introduction, p.172.

${ }^{43}$ BENTHAM, Jeremy, An Introduction, p.173. Emphasis is Bentham's.

${ }^{44}$ BENTHAM, Jeremy, An Introduction, p.57.

${ }^{45}$ BENTHAM, Jeremy, An Introduction, p.180. Emphasis is Bentham's.
} 


\section{Conclusion: what we are not arguing}

To avoid misunderstandings, it should be clear that we are not arguing that Bentham and Mill never use the words "value", "quantity" and "quality" in other acceptations than those we have examined here. It would be pedantic and wearisome for a writer in philosophy or politics to always use technical words, as is done in geometry, for example. So, utilitarian writers (including Mill and Bentham) sometimes use more familiar expressions, and instead of speaking of "the value" of something they speak of "the amount", "the quantum", "the magnitude", "the sum", "the aggregate", or ... "the quantity" of pleasure it gives. If one uses the word "quantity" in this sense - as a synonym for "total value" - it is perfectly true then that a consistent utilitarian takes "only quantity" into consideration. This simply means that when evaluating something, we should take only its value into account. But it is not legitimate to oppose this way of speaking to Mill's famous arguments on "quality" since Mill does not use the word "quantity" in this loose sense (as a synonym for "total value").

We are also not arguing that Bentham and Mill held the same opinions concerning the value of poetry, for example, or concerning any other subject. We are simply arguing that there is no serious reason for accusing John Stuart Mill of inconsistency because of his famous phrase on "the quality" of pleasures. As there also seems to be no serious reason for believing that Bentham refused to take "quality" into consideration in the evaluation of pleasures and pains.

And we are not saying here that the properties or characteristics that Bentham included under the word "quality" were as numerous and diversified as those that Mill was thinking about, when speaking of pleasures.

\section{SOME DEFINITIONS.}

In the literature on this subject, the words "utilitarian", "happiness", "pleasure", etc. are used in many different ways. For clearness' sake then, I will identify the sense in which some these words are used here.

- Utilitarianism is the name John Stuart Mill calls his ethical doctrine. By this expression is meant the doctrine according to which "happiness" is the highest good in life and the "happiness of the community" the standard of right and wrong in questions of morality and legislation. Nothing else is meant by this word. No psychological theory is implied.

- By happiness is meant "an existence exempt as far as possible from pain, and as rich as possible in enjoyments", "an existence made up of few and transitory pains, many and various pleasures". 46

${ }^{46}$ MILL, John Stuart, Utilitarianism, p.215. 
- The word pleasure (in the utilitarian definition of "happiness") comprises "the most refined and subtle intellectual and moral gratifications, no less than the coarser and more definite sensual enjoyments". ${ }^{47}$

- Similarly, the word pain includes not only wounds and sicknesses of the body but all unpleasant feelings as humiliations, fear, feelings of injustice, insecurity, etc.

- By the expression a lot of, Bentham does not mean "a large amount" or "a great quantity" of something. He means "a number of things regarded as a group", a basket of different articles. The expression un lot de is more common in French. Larousse gives the following definition:

Ensemble d'articles, d'objets assortis, de marchandises vendues ensemble : Un lot de chaussures, de ferraille.

- Nowadays the word sensations is used in a very large sense, almost as a synonym of "feelings". We use it here in the more restrictive acceptation of Locke, Hartley and the two Mills, reserving it to indicate those states of mind whose immediate antecedent is a state of body:

Feelings are of four sorts: Sensations, Thoughts, Emotions, and Volitions (...) A mind does not, indeed, like a body, excite sensations, but it may excite thoughts or emotions. ${ }^{48}$

- The word satisfactions is often used as a synonym of "pleasures" and the expression satisfied as a synonym for "happy". In Utilitarianism, Mill uses the word in a different and less extensive sense, indicating by it those feelings of appeasement that follow the fulfilment of our desires and inclinations, and indicate that that we have had enough, that we do not desire more, that we are sated or satiated. In this sense, to be satisfied is a synonym of being content (to have obtained what we desired). This is why Mill says "It is better to be a human being dissatisfied than a pig satisfied"; he does not say "It is better to be an unhappy human being than a happy pig".

Whoever supposes that this preference takes place at a sacrifice of happiness - that the superior being, in anything like equal circumstances, is not happier than the inferior - confounds the two very different ideas, of happiness, and content. ${ }^{49}$

\footnotetext{
${ }^{47}$ SiDGwICK, Henry, The Methods of Ethics, Macmillan, 1907, Hackett, Indianapolis, 1981, p.127.

${ }^{48}$ MILL, John Stuart, A System of Logic, p.75.

${ }^{49}$ MILL, John Stuart, Utilitarianism, p.212.
} 